\title{
BAHASA PEREMPUAN MERIGI SAKTI DAN PT. CBS BENGKULU TENGAH DALAM KONFLIK LINGKUNGAN
}

\author{
Nurlianti Muzni dan Prahastiwi Utari \\ Program Studi Magistser Ilmu Komunikasi \\ Fakultas Ilmu Sosial dan Ilmu Politik \\ Universitas Sebelas Maret \\ nurlimuzni@gmail.com \\ prahastiwi@staff.uns.ac.id
}

\begin{abstract}
Abstrak
Tulisan ini merupakan bagian penelitian kualitatif studi kasus pasca konflik lingkungan yang terjadi di Kecamatan Merigi Sakti Kabupaten Bengkulu Tengah Provinsi Bengkulu. Perempuan Merigi Sakti hanyalah representasi dari suara-suara perempuan yang "terbungkam" selama konflik dan pasca konflik oleh karena sistem sosial ataupun birokratis. Pentingnya memahami bahasa tutur perempuan dalam konflik karena perempuan dapat bercerita sesuai dengan apa yang menjadi keluhan dasar masyarakat desa ketika kehidupan mereka terganggu. Perempuan (khususnya perempuan desa) sebagai penyedia pangan oleh peran gender tradisional mereka, juga sebagai pihak yang paling bertanggungjawab atas pengasuhan anak dan mengurus rumah tangga. Penelitian ini menunjukkan adanya kontradiktif yang terjadi antara perempuan dan masyarakat di Merigi Sakti. Suara perempuan Merigi Sakti lebih tertarik menekankan hubungan mereka satu sama lain.
\end{abstract}

Kata kunci: bahasa; perempuan; konflik lingkungan; gender; merigi sakti

\begin{abstract}
s
This paper is part of a qualitative research with case study approaches of post-conflict environmental that happen in Merigi Sakti Sub-district, Central Bengkulu Regency, Bengkulu Province. Women in Merigi Sakti are just a representation of female voices that are "silenced" during conflict and post conflict because of social or bureaucratic system. The importance of understanding the speech language of women in conflict because women can tell stories in accordance with what is the basic complaint of the village community when their lives are disturbed. Women (especially rural women) as food providers by their traditional gender roles, as well as those most responsible for child care and housekeeping. This study shows the contradictions that occur between women and men in Merigi Sakti. The voices presented by women in Merigi Sakti emphasize more on each other's relationships and the voices associated with domestic activities in women.
\end{abstract}

Keywords: language; women; environment conflict; gender; merigi sakti

\section{Pendahuluan}

Perempuan dan lingkungan merupakan dua energi yang tidak bisa dipisahkan, bagaikan akar dan batang yang keduanya akan saling menghidupi. Begitulah awal tulisan ini dibuat, berdasarkan analisa yang berusaha mensinergikan antara perempuan dan alam. Penulis melakukan analisa ini berdasarkan pada pengalaman akademis ketika melakukan penelitian di daerah pasca konflik yang terjadi di Merigi Sakti Kabupaten Bengkulu Tengah Provinsi Bengkulu. Perempuan Merigi Sakti hanyalah representasi dari suara-suara perempuan yang "terbungkam" selama konflik dan pasca konflik oleh karena sistem sosial ataupun birokratis yang telah menempatkan posisi perempuan jauh sebelum kenyataan banyaknya konflik lingkungan yang terjadi di Indonesia.

Gender, merupakan kata yang paling mudah untuk menjelaskan fenomena yang terjadi ketika perempuan tidak mampu bersuara secara verbal selama konflik, hingga pasca konflik. Walaupun pada kenyataannya, selama di lapangan peneliti membaca bahasa-bahasa non-verbal perempuan Merigi Sakti yang "berbicara" dengan cara mereka sebagai bentuk partisipasi, protes, ataupun penolakanpenolakan lain yang tidak bisa mereka suarakan langsung. Situasi geografis Indonesia sangat mendukung untuk memandang hal ini serta menjadi salah satu kajian dengan menggunakan perspektif komunikasi. Disamping sudah semakin banyak jejak akademis yang menuliskan mengenai kondisi 
perempuan dan berbagai konflik agraria ataupun konflik ekologi yang muncul diberbagai daerah. Catatan dari HUMA (Perkumpulan untuk Pembaharuan Hukum Berbasis Masyarakat dan Ekologis) menemukan bahwa terdapat 332 konflik yang tersebar disektor pengelolaan Sumber Daya Alam seperti kehutanan, perkebunan, pertambangan, pertahanan dan perairan. ${ }^{1}$

Kembali pada persoalan sebelumnya, bahwa pandangan masyarakat yang melihat perempuan dalam situasi konflik bermacammacam, ada yang positif dan juga negatif. Tentu hal tersebut bukanlah suatu jawaban. Namun yang terpenting adalah peran perempuan dalam konflik lingkungan dari cara mereka mengkomunikasikan penolakan mereka seringkali terabaikan bahkan dianggap tidak terlibat apapun. Dari tulisan inilah penulis mencoba mengemukakan peran perempuan dalam wilayah konflik lingkungan, dengan melihat cara mereka bertutur serta mengajukan berbagai penolakan dengan bahasa mereka. Dengan begitu maka akan ditemukan bahwa peran, tidak seluruhnya berbentuk suara-suara verbal yang bisa didengar. Namun dengan bahasa non verbal dan menyuarakan penolakan. Sehingga akan ditemukan apakah perempuan telah berperan dalam suatu situasi konflik.

\section{Perempuan dalam Konflik}

Wacana gerakan perempuan global yang menyebar ke Indonesia merupakan hasil rujukan dari kelompok perempuan untuk melakukan perlawanan ataupun pembelaan terhadap perempuan. Gerakan tersebut disusun dan ditransformasikan oleh sekelompok perempuan kelas menengah, berpendidikan barat, dan memiliki jaringan regional maupun Internasional. Isi narasi besar feminisme global

\footnotetext{
1 Andiko dan Harry Oktavian. 2014. Negosiasi Efektif untuk Konflik Sumber Daya Alam. Pekanbaru: Scale Up.
}

adalah hak perempuan, kesetaraan, hak properti, hak kepemilikan perempuan dalam perkawinan, ekploitasi ekonomi, seksualitas, kekerasan dan poligami. Isu-isu tersebut dibawa dan diwacanakan relatif sama di Indonesia. $^{2}$

Namun disisi yang berbeda, kompleksitas permasalahan perempuan tidak hanya berkaitan dengan isu mainstream yang kebanyakan terilhami dari permasalahan perempuan global tersebut. Permasalahan lokal, yang berimbas pada perempuan juga seharusnya menjadi perhatian bagi gerakan perempuan saat ini sehingga tidak menjeneralisasi permasalahan perempuan sampai ke akar rumput. Konteks lokal memang belum banyak tertulis dalam karya-karya ilmiah, namun sudah mulai mendapat perhatian bagi kebanyakan kelompok gerakan perempuan. Isu Lokal, selain cenderung berbeda dengan isu mainstream secara umum, gerakan perempuan dari kelompok subaltern memang menempuh jalan perlawanan secara tersembunyi dan melalui simbol. ${ }^{3}$ Rata-rata perlawanan mereka menyangkut keberlangsungan hidup respons atas permasalahan lingkungan yang tidak diatasi sejak lama. Keterlibatan mereka-pun belum mampu terdengar seperti isu-isu yang bergerak diwilayah perkotaan yang mampu menggunakan dan mengambil alih sebagian sumber informasi.

Keterlibatan perempuan dalam konflik misalnya, menuliskan bahwa perempuan tidak hanya menjadi korban dalam suatu konflik tertentu. Namun juga terlibat serta berperan dalam konflik itu sendiri. Baik dalam upaya penyelesaian konflik, maupun menjadi bagian penting di dalamnya. "...It has been noticed in different conflicts that women are not only victims of war but also active participants.

\footnotetext{
2 Kartika, Titiek. 2014. Perempuan Lokal vs Tambang Pasir Besi Global. Jakarta:Yayasan Pustaka Obor Indonesia

3 ibid hal. 39
} 
Women can be involved not only as nurses, mothers of disappeared, keepers on the home front in times of war, but also in the role of those who commit serious atrocities and abuses". Guhathakurta juga menuliskan, untuk lebih memahami dampak dan kekuatan perempuan selama masa konflik internasional, dapat mengambil contoh analisa dari peran perempuan untuk perdamaian di Liberia. Pengaruh perempuan dapat digambarkan dalam kontribusi mereka yang mencakup kegiatan akar rumput. Perempuan mencoba memainkan peran mereka sesuai dengan apa yang menjadi keseharian mereka.

Menurut Guhathakurta peran perempuan dalam membangun perdamaian dapat di bagi ke dalam tiga kategori yakni,women's actor,women's agenda, dan women's perception. Pertama mengenai women's actor, perempuan dapat dilihat baik sebagai korban, pejuang maupun pelaku di dalam konflik. Peran perempuan sebagai konektor yang mampu melewati batas konflik dapat di lihat dari kelompok perempuan Israel yang mendeklarasikan solidaritasnya dengan kelompok perempuan Pakistan di tengah-tengah konflik yang terjadi serta kelompok yang terbentuk antara Bosnia, Kroasia, dan Serbia pada saat krisis Bosnia. ${ }^{5}$ Perempuan sebagai aktor dalam perdamaian dicontohkan pula oleh Naga Mothers Association yang bergerak dalam menghadapi perselisihan antar fraksi dan etnis di India dengan memobilisasi dialog antar pemerintah negara bagian barat dan mengorganisir demonstrasi publik dengan para pemimpin agama untuk menyuarakan perdamaian dan penolakan terhadap pembunuhan. ${ }^{6}$

Kedua, women's agenda berisikan agendaperempuan dalammembangun

\footnotetext{
${ }^{4}$ Guhathakurta, Meghna. 2004. Women in Peacebuilding. Diakses pada 6 Desember 2016. Pukul 15:16 WIB.

${ }_{6}^{5}$ Loc.cit
}

perdamaian utamanya dalam menghadapi kekerasan yang di alami oleh perempuan dalam situasi konflik. Dalam beberapa kondisi perempuan tidak mendapatkan ruang untuk menyuarakan apa yang menjadi kebutuhan mereka pada saat konflik terjadi. Hal yang kemudian mendorong perempuan untuk menghimpun kekuatan mereka dalam bentuk kelompok dan mengagendakan apa yang akan mereka lakukan bersama-sama. Terakhir, mengenai women's perception menjadi hal penting untuk menggabungkan aspirasi dan persepsi para perempuan dalam melihat konflik dan bagaimana perempuan melihat keterlibatan dirinya dalam konflik tersebut. ${ }^{7}$

Perempuan terlibat dalam proses perdamaian berupa perjanjian perdamaian, rekonstruksi berkelanjutan dan keefektifan perempuan (menjalankan peran-peran sosial yang konstruktif dalam masyarakat). ${ }^{8}$ Perempuan telah terlibat dalam proses perdamaian yang bersifat informal selama perang manusia terjadi. Proses informal ini, yang ditulis oleh Guhathakurta mengambil banyak bentuk dari kelompok kecil dan bertindak secara sistematis dan terorganisir. Bentuk advokasi yang dilakukan oleh perempuan dalam menyembuhkan luka pasca perang juga berperan penting dalam membangun hubungan dan saling menemukan pemahaman dalam budaya.

Kembali ke konteks lokal, bahwa peran perempuan dalam konflik menyebar ke berbagai daerah. Anugrah geografis yang melimpah bagi Indonesia telah menunjukkan wajah baru bagaimana manusia memperlakukan alam di masa modern saat ini. Dimana penguasa dan kekuasaan mencoba melindungi kelompok berkepentingan untuk

\footnotetext{
${ }^{7}$ Loc.cit

${ }^{8}$ Laura Kray \& Linda Babcock. 2015. "Gender in Negotiations: A Motivated Social Cognitive Analysis, in Negotiation Theory and Research 203" (Leigh L. Thompson ed., 2006) Shepherd 2015.
} 
mengekploitasi alam yang sering kali merugikan masyarakat sekitarnya, perlawananperlawanan yang dilakukan oleh masyarakat beberapa diantaranya berakhir konflik berkepanjangan serta berimbas pada sektor lainnya, seperti ekonomi, sosial, politik, dan lain-lain. Berdasarkan catatan akhir tahun Konsorsium Pembaruan Agraria (KPA) sepanjang tahun 2015 sedikitnya telah terjadi 252 kejadian konflik agraria di tanah-air, dengan luasan wilayah konflik mencapai 400.430 Hektar. Konflik-konflik tersebut melibatkan sedikitnya 108.714 Kepala Keluarga (KK). ${ }^{9}$ Rata-rata penyelesaian konflik lingkungan tidak selesai dalam jangka waktu yang sebentar bahkan masih berlanjut hingga saat ini.

Eksploitasi Sumber Daya Alam yang berlebihan oleh pemilik modal serta dukungan dari pemerintah yang membuat mereka semakin "melenggang" mengakibatkan penggusuran secara paksa terhadap masyarakat lokal. Atas nama pembangunan serta pemanfaatan sumber daya alam, secara langsung mereka dipisahkan dan dimarjinalkan dari ruang mereka sendiri. Hal ini dipandang sebagai paradoks pembangunan ekonomi yaitu tingginya pertumbuhan ekonomi tidak diikuti dengan peningkatan kualitas kehidupan sosial masyarakat. ${ }^{10}$ Para perempuan di pedesaan Indonesia, kerap kali diposisikan sebagai penyedia pangan oleh peran gender tradisional mereka, juga sebagai pihak yang paling bertanggungjawab atas pengasuhan anak dan mengurus rumah tangga. ${ }^{11}$ Menurut Soentoro situasi tersebut mendorong perempuan perlu berbicara mengenai lingkungan dan sumber

\footnotetext{
9 Catatan Akhir Tahun Konsorsium Pembaruan Agraria tahun 2015.

${ }^{10}$ Usboko, Ignasius. (2016). Role Players Analysis dalam Konflik Pengelolaan Sumber Daya Alam

(Studi Kasus Konflik Pertambangan Mangan Di Kabupaten Timor Tengah

11 Buletin DTE edisi khusus No 99-100, Oktober 2014.
}

daya alam, karena industrialisasi atau pembangunan. ${ }^{12}$

Begitu juga bagi perempuan yang hampir disetiap waktunya sangat tergantung dengan alam. Mereka semakin terpisahkan oleh kehidupan mereka sendiri serta peran mereka yang semakin tak dianggap bagi keberlangsungan alam. Konstruksi jender yang masih menempatkan perempuan sebagai pemelihara keluarga dan rumah tangga, membuat perempuan harus berpikir lebih dalam menyediakan makanan, air bersih, dan kebutuhan rumah tangga lainnya, hingga dalam hal pendidikan anak-anaknya. ${ }^{13}$

Gerakan perempuan yang berbasis lingkungan sering disebut "ekofeminis", yang merupakan suatu istilah baru untuk gagasan yang telah lama diungkapkan. Istilah ini pertama kali dipergunakan oleh Francoise

D"eaubonne pada 1974 dalam artikel Le Feminisme ou la Mort (feminisme atau mati) ${ }^{14}$ namun menjadi populer dalam kaitannya dengan berbagai protes dan aktivitas menentang perusakan lingkungan hidup. ${ }^{15}$ Hunga menuliskan para ekofeminis mengungkapkan bahwa peran gender yang diberikan perempuan menyebabkan mereka mempunyai kepekaan dan kedekatan dengan alam. ${ }^{10}$ Dalam masyarakat yang menjadikan

\footnotetext{
${ }^{12}$ Umar, Risma (edtr). (2012). Mengurai Realita Pemiskinan Perempuan di Tengah Konflik Sumber Daya Alam: Merekam Kasus-kasus Konflik Sumber Daya Alam. Solidaritas Perempuan (2008-2011). Soemarmo merupakan salah satu penulis dalam buletin Solidaritas ${ }_{13}$ Perempuan - pada bagian pengantar 14 Dony Danardono. (2013). "Ekofeminisme: Kontradiksi Kapitalisme dan Etika Kepedulian".

Ekofeminisme Dalam Tafsir Agama, Pendidikan, Ekonomi dan Budaya. 43-54

15 Shiva, Vandana dan Maria Mies. (2005). Ecofeminism perspektif gerakan perempuan dan lingkungan. Yogyakarta: Ire Press

16 Hunga, Arianti Ina R. (2013). Ekofeminisme, Krisis Ekologis dan Pembangunan Berkelanjutan. Dalam Ekofeminisme (dalam tafsir agama, pendidikan, ekonomi dan Budaya).
} 
alam dan tanah sebagai sumber kehidupan, dimana hubungan yang tercipta tidak sekedar material, terjalin interkoneksi yang intin antara bumi dan masyarakatnya. ${ }^{17}$ Pusat Kajian Wanita dan Gender Universitas Indonesia dalam Seminar Series \#2 menyampaikan bahwa ekofeminisme sebagai teori etika lingkungan hidup menyodorkan cara pandang yang baru, yaitu menggugat cara pandang dominan masyarakat modern, lalu menggantikannya melalui perilaku yang baru dalam mengatasi krisis lingkungan. ${ }^{18}$ Dapat diartikan bahwa ekofeminis merupakan pengejawantahan secara teoritis bagaimana memperlakukan alam secara bijaksana melalui perspektif feminis yang memandang alam sebagai bagian dari kehidupan.

\section{Kronologis Perjuangan Masyarakat Merigi Sakti dalam Konflik}

Pada tahun 2009, kegiatan penambangan batubara telah dilakukan oleh Manajemen Lama PT. Citra Buana Seraya (CBS) yaitu dengan cara memberikan Surat Perintah Kerja (SPK) kepada PT. Multi Sinar Kencana (PT. MSK) sebagai pelaksana kegiatan penambangan secara terbuka (open pit). ${ }^{19}$ Luas lahan tambang yang telah dibuka untuk usaha penambangan batubara oleh PT. MSK selama kurun waktu 2010 hingga 2013, diperkirakan mencapai luas lahan sekitar 63 Ha. Lahan tambang yang telah dibuka tersebut berada di wilayah Lubuk Unen Baru (blok II, III, dan IV), Kecamatan Merigi Kelindang Bengkulu Tengah. Kegiatan ini berakhir pada pertengahan tahun 2013. ${ }^{20}$ Berdasarkan informasi dan pemantauan peneliti dilapangan, galian yang dilakukan secara terbuka (open pit)

\footnotetext{
${ }^{17}$ Shiva, Vandana dan Maria Mies. Op.cit

18 PKWG Seminar Series \#2: Perempuan, Eksploitasi Alam, dan Pemiskinan" terselenggara di Auditorium Juwono Sudarsono FISIP UI Kampus UI Depok pada 17 September 2015.

${ }^{19}$ Data lapangan 2017

20 Berdasarkan catatan Analisis Dampak Lingkungan (ANDAL) yang disetujui oleh Badan Lingkungan Hidup Provinsi Bengkulu (BLH).
}

ini meninggalkan bekas dalam arti bahwa reklamasi yang tidak selesai. Lubang-lubang yang terlihat seperti kolam masih ada disekitar tanah warga dan didekat jalan lintas.

Bulan Mei 2013 telah dilakukan pengalihan saham PT. CBS dari pemilik saham lama kepada pemilik saham baru atau investor baru. Selanjutnya direncanakan untuk melaksanakan kegiatan produksi tambang terbuka yang dijadwalkan pada Kuartal III tahun 2013, namun tidak dapat direalisasikan. Hal ini disebabkan dari hasil survei pemetaan Geologi detail dan pengeboran yang telah dilakukan pada tahun 2013, biaya produksi tinggi karena SR rata-rata secara umum telah mencapai $>1: 16$, kenaikan harga solar industri mencapai $100 \%$, sementara harga jual di pasar dunia menurun. ${ }^{21}$ Maka disimpulkan bahwa rencana upaya produksi tambang terbuka menjadi kurang ekonomis. Sehingga pihak manajemen baru memutuskan untuk melakukan perubahan metode teknik penambangan dan status perijinannya dari Izin Usaha Pertambangan-Operasi Produksi (IUPOP) tambang terbuka (open pit) menjadi tambang bawah tanah (underground).

Dari hasil penelitian lanjutan tentang potensi cadangan batubara di wilayah IUP-OP PT. CBS didapatkan jumlah cadangan dari 4 (empat) indikasi lapisan batubara yang ada yaitu total sekitar 15.840 .500 ton. Rencana kapasitas produksi adalah sekitar 300.000 ton/tahun. Berdasarkan rumusan yang umum dan metode tambang bawah tanah yang digunakan, maka diperkirakan umur tambang tersebut adalah sekitar 32,5 tahun.

Tuntutan dan penolakan masyarakat terhadap PT. CBS telah disampaikan sejak lama. Berdasarkan dokumen dari LSM Genesis menuliskan bahwa, minimal sejak tahun 2015 masyarakat di dua kecamatan, Kecamatan Merigi Kelindang dan Kecamatan Merigi Sakti Kabupaten Bengkulu Tengah telah menyampaikan penolakannya mereka kepada Pemerintah Bengkulu Tengah.

${ }^{21}$ Sumber Data: Genesis Bengkulu dan WALHI 
Antara lain pada tahun 2015 tercatat penolakan ini disampaikan pada tanggal 7 Oktober 2015 dan 13 November 2015 disampaikan oleh Warga Desa Susup, Kecamatan Merigi Sakti kepada pemerintah Kabupaten Bengkulu Tengah. Masyarakat menuntut untuk menutup perusahaan tambang batubara yang berada didekat wilayah mereka, bahkan mereka juga mengancam akan menutup tambang batu bara PT. CBS jika pemerintah daerah tidak melakukan tindakan. Konflik antara masyarakat dengan perusahaan serta tuntutan yang disampaikan oleh masyarakat dipicu oleh proses ganti rugi lahan, penggalian tambang terbuka yang berada di sepanjang pinggir jalan, lobang bekas tambang tidak direklamasi/ditutup kembali, tidak diperbaiki dan rusaknya jalan desa dan kecamatan akibat pengakutan batubara, dan perpindahan metode oprasi produksi dari metode tambang terbuka (open pit) ke penggalian bawah tanah (underground). ${ }^{22}$

Ditambahkan pula berdasarkan data lapangan, masyarakat melalui Kepala Desa dan perwakilan Forum Masyarakat Rejang Gunung Bungkuk (FMRGB) menolak perusahaan tambang batubara (PT Cipta Buana Seraya) di wilayah mereka yang merubah sistem tambang menjadi bawah tanah. Masyarakat merasa bahwa sistem tambang bawah tanah tidak aman bagi desa dan anak cucu mereka. Selain itu, berdasarkan hasil analisa dan data yang dilakukan oleh masyarakat sistem underground membawa kerugian berupa hilangnya air tanah (air sumur) sehingga tanah-tanah disekitar mereka menjadi retak-retak, serta ketakutan tanah ambles (runtuh) di waktu-waktu yang tidak bisa mereka prediksi. Mereka merasa telah melakukan upaya dialog dan menyampaikan aspirasi mereka kepada pemerintah maupun perusahan.

\section{Pandangan Teoritis Bahasa dan Gender dalam Konteks Konflik Lingkungan di Indonesia}

22 Data lapangan, 2017
Tiga puluh tahun yang lalu, sebuah karya besar telah dihasilkan dalam komunikasi dan gender. Teori ini akan berhubungan dengan gender sampai tradisi sosial budaya. Semua teori ini terkait dengan bagaimana gender mempengaruhi bahasa dan sebaliknya membangun sebuah dunia sosial khusus. ${ }^{23}$

Cheris Kramarae merupakan orang yang meyakini bahwa fitur utama dari dunia adalah sifat linguistiknya serta kata-kata dari sintaksis dalam struktur pesan dari pemikiran seseorang. Interaksi mempunyai pengaruh besar pada cara kita mengarungi dunia. Implikasi yang timbul dari bahasa berdasarkan perhatian utama Kramarae adalah pada bagaimana cara pesan memperlakukan perempuan dan pria secara berbeda. ${ }^{24}$ Pengalaman seseorang tidak mungkin lepas dari pengaruh bahasa. Bahkan kategori lakilaki dan perempuan adalah hasil dari pembentukan secara linguistik. Dalam artian yang lebih khusus adalah penjelasan bahwa bahasa merupakan konstruksi sosial masyarakat yang dibentuk berdasarkan kesepakan serta termaknai berdasarkan konteks tinggal masyarakat tersebut. Menurut Burman \& Parker bahwa bahasa memiliki kategori dasar yang kita gunakan untuk memahami diri kita sendiri, yang mempengaruhi cara kita bertindak sebagai perempuan atau sebagai lakilaki dan mendefinisikan identitas budaya kita sendiri. $^{25}$

Masyarakat mempunyai berbagai cara untuk menyuarakan kepentingan mereka. salah satu hal yang sering terjadi sebelum konflik terjadi adalah demonstrasi massa masyarakat sebagai upaya negosiasi serta pengajuan protes kepada pihak yang bertanggungjawab (dalam hal ini biasanya pemerintah dan lembaga

\footnotetext{
23 Kramarae, dalam Littlejohn\&Foss. Theories of Human Communication tenth Edition. 2011

${ }^{24}$ Loc.cit

25 Nazir, Barirah. (2012). Gender Patterns on Facebook: A Sociolinguistic. International Journal of Linguistics ISSN 1948-5425 2012, Vol. 4, No. 3. doi:10.5296/ijl.v4i3.1899
} 
eksekutif). Masyarakat yang majemuk akan menjadi satu ketika mereka mempunyai satu kepentingan yang sama. Salah satu misalnya masyarakat Merigi Sakti Kabupaten Bengkulu Tengah.

Hal yang sering terlupakan ketika berbicara mengenai peran perempuan dalam kasus konflik lingkungan adalah bagaimana cara mereka menyuarakan penolakan mereka. Berdasarkan perspektif tersebut tampak jelas bahwa perempuan dan laki-laki akan mencari hal yang berbeda dalam permainan bahasa mereka. Perempuan lebih tertarik menekankan hubungan mereka satu sama lain, sedangkan laki-laki akan lebih tertarik menegaskan otonomi (autonomy) mereka, "Whereas women might be more interested in emphasizing their connection to each other, men would be more interested in asserting their autonomy". ${ }^{26}$

Kramarae tidak hanya mencatat kepentingan bahasa dalam penafsirannya, ia juga mengarahkan pada dimensi kekuasaan.

Sistem bahasa memiliki hubungan kekuasaan yang ditambahkan di dalamnya dan mereka yang menjadi bagian dari sistem linguistik yang dominan, cenderung memiliki persepsi mereka sendiri, mengalami dan memiliki mode ekspresi yang menyatu dalam bahasa. Perkataan yang tidak memiliki kekuatan (power), pada gilirannya membuat orang-orang memperlakukan perempuan seolah-olah mereka benar-benar tidak berdaya. ${ }^{27}$ Menurut Fishman dan West dalam dokumentasi mereka mengenai dominasi percakapan (speech) perempuan dan laki-laki, "men and women and men"s speech have been

26 Eliasoph, Nina. (1987). Politeness, Power, and Women's Language: Rethinking Study in Language and Gender. Berkeley Journal of Sociology, Vol. 32 (1987), pp. 79-103Published by: Regents of the University of CaliforniaStable 2014.

27 hal. 84 labelled as powerful speech while women"s speech are powerless speech", 28

Kramarae mencatat bahwa karena perempuan secara verbal bisu, maka perempuan lebih bergantung pada bahasa nonverbal dan menggunakan bahasa non verbal yang berbeda dengan laki-laki. Perempuan menunjukkan ekspresi mereka dalam keragaman percakapan mereka. Sebagai akibat dari menjadi bungkam, perempuan merespon dalam berbagai cara. Salah satunya perempuan menciptakan ekspresi mereka sendiri di luar dominasi sistem laki-laki. Mohindra and Azhar menuliskan dalam jurnal mereka bahwa perempuan menafsirkan komunikasi nonverbal lebih baik daripada laki-laki. Laki-laki kurang nyaman untuk membuat kontak mata dari pada perempuan. Rupanya, itu ada hubungannya dengan dominasi, kekuasaan dan status. Kontak mata langsung adalah tanda emosi. Jadi, kontak mata kurang berbagi sedikit emosi. Tapi, pada dasarnya, pria dan perempuan menggunakan gerak tubuh, postur, sentuh dan ekspresi wajah yang berbeda. Misalnya, perempuan cenderung untuk tersenyum dan menggunakan ekspresi wajah yang lebih daripada pria. ${ }^{29}$

Foss and Foss dalam bukunya "Women Speak: The Eloquence of Women's Lives" dengan mewawancarai sejumlah perempuan dan menguji bentuk komunikasi mereka. Dalam buku tersebut menunjukkan bahwa banyak bentuk komunikasi yang digunakan perempuan bernilai dalam kewenangan mereka

28 Ogunsiji, Yemi, Farinde R.O, \& Adebiyi C.O. (2012). "Language, Gender and Culture". British Journal of Arts and Social Sciences ISSN: 2046-9578, Vol.6 No.2. British Journal Publishing, Inc.

29 Mohindra, Vinita and Samina Azhar. (2012).

Gender Communication: A Comparative Analysis of Communicational Approaches of Men and Women at Workplaces. IOSR Journal of Humanities and Social Science (JHSS) ISSN: 2279-0837, ISBN: 2279-0845. Volume 2, Issue 1 $\begin{array}{llll}\text { (Sep-Oct. } & \text { 2012), } & \text { PP } & \text { 18-27 }\end{array}$ www.iosrjournals.org 
sendiri, walaupun dianggap tidak signifikan dalam publik dunia maskulin. 30

Kramarae adalah seorang penyokong yang ingin melihat perempuan membuat dunia yang aman untuk kebebasan dan penggalian ide-ide kritis. Sangatlah penting untuk melihat dan mempelajari bahasa perempuan dan komunikasi kelompok lain yang terpinggirkan untuk lebih belajar mengenai bentuk komunikasi alternatif. Karya bahasa dan kekuasaan menggambarkan sebuah cara bagi karya akademisi feminis untuk meningkatkan kesadaran tentang hubungan kekuasaan dan menyarankan strategi untuk meningkatkan kekuatan perempuan.

\section{Bahasa tutur Perempuan Merigi Sakti dalam menyampaikan pendapat saat konflik}

Bahasa merupakan salah satu unsur kebudayaan; artinya, bahasa hanyalah bagian dari sekumpulan unsur dalam kebudayaan (kesenian, sistem religi, sistem ekonomi, sistem sosial, dll). Sebagian unsur lainnya juga mewadahi segala kekayaan kebudayaan yang tercermin lewat bahasa-bahasa yang ditampilkan.

Manusia terbentuk sebagai makhluk sosial yang mempunyai banyak kebutuhan, mulai dari kebutuhan biologis, spritual, maupun kebutuhan sosial yang selalui ingin dipenuhi. Sosialisasi, yang merupakan bagian dari komunikasi yang di dalamnya terjadi pertukaran ide, pesan, dan makna, namun tidak jarang terjadi kesalahpahaman dalam proses penyampaian dan penerimaan pesan.

Dalam menyampaikan pesan, manusia membutuhkan bahasa sebagai medium untuk saling memahami. Definisi bahasa secara fungsional melihat bahasa secara fungsinya, sehingga bahasa diartikan sebagai alat yang dimiliki bersama untuk mengungkapkan

30 Foss, Karen A. and Sonja K. Foss. 1991. Women Speak: The Eloquence of Women's Lives. Waveland Pr Inc (March 1991) gagasan (socially shared means for expressing ideas), sedangkan definisi formal menyatakan bahasa sebagai semua kalimat yang terbayangkan yang dapat dibuat menurut peraturan tatabahasa. ${ }^{31}$ Berdasarkan dari fungsinya, bahwa bahasa menjadi alat bagi manusia untuk bertukar pesan yang terhubung lewat simbol maupun ucapan.

Bahasa biasanya terbentuk secara berbeda-beda. Sesuai dengan tingkat suasana dan lingkungan yang melingkupi kehidupan manusia. Misalnya perbedaan letak geografis membedakan bahasa yang dibawa oleh masingmasing daerah. Namun tidak hanya letak geografis, bahasa juga dapat berbeda karena perbedaan jenis kelamin, laki-laki dan perempuan.

Menurut Kramarae bahwa pengalaman seseorang tidak mungkin lepas dari pengaruh bahasa. $^{32}$ Bahkan kategori laki-laki dan perempuan adalah hasil dari pembentukan bahasa, yang kemudian melakukan kegiatan khusus untuk melihat dua hal tersebut. Bahasa akan cenderung memiliki persepsi dari apa yang dialami dan siapa yang mengalami suatu peristiwa. Karena kecenderungan tersebut, maka makna dari bahasa dapat saja berbedabeda serta penerimaan yang mungkin juga akan salah.

Misalnya Jalal menuliskan bahwa bahasa merupakan satu hubungan sosial yang sering menjadi masalah penting dalam kehidupan masyarakat di dalam berbagai perbedaan relasi sosial berdasarkan jenis kelamin.

bahasa memuat istilah-istilah, konsepkonsep, ataupun label-label terkait dengan benda-benda, perilaku, sistem nilai, dan sebagainya. Akhirnya lewat bahasa juga akan terefleksikan pandangan dan penilaian masyarakat atas predikat dan label mana yang

\footnotetext{
31 Rakhmat, Jalaluddin. (2009). Psikologi Komunikasi. Bandung: PT. Remaja Rosdakarya. ${ }^{32}$ Littlejohn, Stephen dan Karen A. Foss. (2011). Theories of Human Communication tenth Edition. Illinois: Waveland Press.
} 
pantas bagi laki-laki dan perempuan. Dengan demikian, bahasa merekam asumsi-asumsi yang diyakini oleh masyarakat mengenai bagaimana seharusnya seorang laki-laki atau perempuan berperilaku. ${ }^{33}$

Dalam konflik lingkungan, perempuan dan laki-laki menampilkan bahasa yang berbeda-beda. Mereka terkonstruksi melalui budaya serta kebiasaan di lingkungan mereka berada. Bentuk-bentuk bahasa tersebut terlihat dalam gerakan-gerakan baik secara langsung maupun tidak langsung, secara verbal ataupun non verbal. Sehingga seringkali kita menjumpai beberapa tokoh ataupun kelompok yang mengatasnamakan kelompok perempuan (misalnya) yang bergerak dalam wilayah konflik.

Kasus konflik lingkungan antara masyarakat Merigi Sakti dan PT. CBS memperlihatkan bagaimana perempuan dan laki-laki bersuara dengan cara mereka. Secara umum mereka bergerak bersama-sama dalam bentuk dialog dan demonstrasi dengan tuntutan yang sama. Masyarakat Merigi Sakti mempunyai alasan yang sama untuk bergerak. Perjuangan mereka adalah membela hak, dari anggapan ketidakadilan yang dilakukan oleh perusahaan. Mereka beranggapan bahwa perusahaan melakukan pekerjaan-pekerjaan yang tidak sesuai dengan kesepakatan dengan masyarakat sejak awal. Misalnya menutup akses pertambangan sehingga masyarakat tidak mengetaui aktivitas didalamnya, memilih orang-orang yang mau menandatangani kesepakatan pergantian sistem, dan lain-lain.

Walaupun demikian bahasa dan cara bertutur antara perempuan dan laki-laki terlihat berbeda. Perbedaan suara yang terdengar pada laki-laki dan perempuan ternyata memang tidak sekadar berbeda dalam hal bunyi, tetapi

\footnotetext{
33 Jalal, Moch. (2009). Fenomena Bias Gender dalam Pemakaian Bahasa Indonesia. Media Masyarakat Kebudayaan dan Politik. Volume : 22 - No. 2 - 2009-04-01
}

oleh banyak orang suara bisa diartikan sebagai sifat. ${ }^{34}$ Antusias dan isi pesan yang diceritakan oleh ibu-ibu Merigi Sakti yang terlibat dalam konflik berbeda dengan apa yang disampaikan oleh laki-laki yang peneliti temui. Ibu Kades Desa Komering, misalnya, tidak ingin bercerita secara rinci mengenai ketakutan dan hambatan yang ia rasakan saat konflik terjadi. Berdasarkan footnote yang peneliti dapatkan melalui obrolan-obrolan di dapur, perempuan Merigi Sakti sangat tertekan selama konflik terjadi. Mereka sangat merasakan bagaimana perekonomian mereka yang dihitung melalui

"isi dapur" berkurang. Belum lagi ketakutan yang muncul sehingga mereka tidak berani untuk keluar rumah.

Suara perempuan Merigi Sakti lebih tertarik menekankan hubungan mereka satu sama lain. Penolakan mereka terhadap konflik tambang batu bara di daerah mereka disuarakan dengan cara pendekatan yang dimulai dari keluarga intim, kerabat, tetangga, hingga orang-orang terdekat yang mereka kenal. Permasalahan yang mereka ajukan juga bersifat domestifikasi, yaitu terganggunya keuangan keluarga mereka yang mengganggu kondisi dapur. Selama konflik terjadi mereka tidak bisa berkebun dengan leluasa sehingga hal tersebut mengganggu penghasilan panen yang seharusnya bisa lebih mereka dapatkan. Di lain hal, keadaan konflik juga membuat pasar yang seharusnya ada di setiap akhir minggu tidak bisa dibuka, dan kebanyakan dari mereka harus masak dan makan sesuai dengan apa yang tersisa.

Ibu Kepala Desa Komering menceritakan bagaimana ia kesulitan untuk mengatur keuangan serta masakan yang harus ia buat setiap harinya. Karena selama konflik terjadi suaminya tidak dapat dengan bebas berkebun. Selain itu, selama dua bulan lebih saat konflik pecah (penembakan warga) dan

\footnotetext{
34 Katubi. (2005). Membaca Posisi Wanita Melalui Bahasa: Deretan Temuan Penelitian Tanpa Implikasi Teoretis. Jurnal Masyarakat dan Budaya, Volume VII No. 2 Tahun 2005
} 
pascanya untuk keluar rumah-pun beliau tidak berani.

Cerita-cerita ini tidak akan peneliti dapatkan selama dalam obrolan-obrolan yang dilakukan seperti yang didapat kan dengan laki-laki dengan wawancara yang dilakukan secara formal. Namun, melalui dapur yang merupakan wilayah territory perempuan desa setiap harinya untuk tetap menjaga isi rumahnya peneliti mendapatkan banyak cerita dan perjuangan ibu-ibu Merigi Sakti. Wilayah yang paling mudah untuk memulai bercerita mengenai ancaman-ancaman yang dirasakan selama mereka melalui konflik tersebut.

Berbeda dengan yang disampaikan oleh ibu-ibu ketika ditemui pada saat obrolanobrolan ringan, sepulang mereka berkebun. Suasana redup dan hangat terlihat ketika memasuki rumah mereka yang juga dipenuhi oleh para tetangga. Obrolan mengenai konflik seakan mengingatkan mereka kembali akan sakit dan ketakutan yang mereka alami selama konflik berlangsung.

Pentingnya memahami bahasa tutur perempuan dalam konflik karena perempuan dapat bercerita sesuai dengan apa yang menjadi keluhan dasar masyarakat desa ketika kehidupan mereka terganggu. Masalah pendidikan, kesehatan, perekonomian (terutama), dan dampak-dampak mendasar lainnya akan ditemui dalam cerita perempuanperempuan dalam konflik. Hasil penelitian ini menunjukkan bahwa apa yang diceritakan oleh perempuan dan laki-laki Merigi Sakti dalam konflik dengan PT. CBS berbeda, walaupun dengan akar masalah yang sama.

Jawaban yang disampaikan oleh perempuan Merigi Sakti memang tidak seluas jawaban yang disampaikan oleh bapak-bapak yang peneliti temui. Namun, jawaban yang disampaikan oleh perempuan Merigi Sakti adalah jawaban mendasar mengapa penolakanpenolakan tersebut disampaikan oleh hampir seluruh masyarakat Merigi Sakti.

"Komunikasi kan bukan cuma bagaimana mereka secara kasat mata terlibat. Tetapi komunikasi bagaimana mereka dibentuk sebagai silent group, atau mereka dari dulu memang tidak bersuara. Perempuan yang dibilang tidak ngapa-ngapain, itu padahal ngapa-ngapain. Perempuan yang berdemo, itu identitasnya terekspose. Tapi kalau ini penolakan yang tersembunyi, sebetulnya komunikasinya adalah bagaimana orang tidak bisa mengetahui yang mereka fikirkan dan mereka simpan. Karena ini bisa sistemis dan kultural. Selain itu bisa mengetahui makna lingkungan bagi mereka" (Titiek

Kartika, akademisi. Dalam kutipan langsung, 21/ 02/2017)".35

Penulis melihat bahwa perbedaan tersebut terkait dengan isi serta latar belakang tuntutan yang mereka sampaikan. Kecenderungan bahwa perempuan menyampaikan apa adanya dengan alasan

"keluarga" terdengar lebih natural seperti yang terdengar dari ibu-ibu di Merigi Sakti. Sedangkan ketika peneliti mendengarkan apa yang diceritakan oleh laki-laki di Merigi Sakti, maka dramatisasi kejadian, serta agenda ekonomi politik terasa lebih kuat disana.

\section{Kesimpulan}

Dalam kondisi konflik lingkungan, tak jarang perempuan berperan sebagai aktor yang menggerakkan serta mengarahkan massa sesuai dengan apa yang mereka gagas dalam gerakannya. Perempuan di Penango, Kabupaten Seluma, Bengkulu salah satunya. Mereka menyuarakan penolakan mereka dengan „cara ${ }^{\text {ee }}$ perempuan bergerak dan bersuara. ${ }^{36}$ Selain itu, berbagai cara lain dari perempuan untuk bersuara dan menyampaikan keinginan mereka selama konflik terjadi.

\footnotetext{
${ }^{35}$ Wawancara dengan Titiek Katika 21 Februari 2017, di Gedung Dekanat Universitas Bengkulu 36 Kartika, Titiek. (2014). Perempuan Lokal vs Tambang Pasir Besi Global. Jakarta:Yayasan Pustaka Obor Indonesia
} 
Perempuan Merigi Sakti, Kabupaten Bengkulu Tengah, berdasarkan data yang dihimpun bahwa peran perempuan ikut menyuarakan aspirasi mereka dalam bentuk demonstrasi, menjaga keamanan keluarga, serta menyuarakan dampak konflik dan lingkungan akibat perusahaan bagi perekonomian keluarga mereka. ${ }^{37}$

Pada dasarnya bentuk gerakan adalah umum. Kemudian digeneralisasi pembagian antara gerakan perempuan dan laki-laki terjadi berdasarkan waktu atau lama konflik tersebut terjadi. Karena pada dasarnya perempuan (khusunya perempuan desa) adalah kelompok yang dibungkam oleh sistem sosial budayanya yang harus selalu berada di dalam rumah (dapur, anak, dll). Sehingga ketika ada dan harus berhimpun dalam gerakan, itu tidaklah mudah bagi perempuan. Pada gerakan tersebut, perempuan butuh proses-proses tertentu dan keadaan yang dapat menguntungkan posisi mereka. Dalam pengertian bahwa ada ruangruang khusus yang diserahkan kepada perempuan untuk mereka bersuara, sehingga memunculkan identitas sendiri berdasarkan perspektif dan pandangan perempuan. Suara perempuan yang tidak dimunculkan, akan memberikan imbas pada ketidakseimbangan proses penyerapan kebutuhan atau permasalahan masyarakat selama konflik terjadi. Suara liyan dari perempuan, merupakan wacana yang sebaiknya segera dimunculkan pada wacana-wacana gerakan masyarakat Indonesia. Sehingga yang dikatakan sebagai gerakan perempuan bukan hanya karena yang melakukan perempuan, tetapi gerakan yang berbeda pada umumnya atau mengupayakan jalan yang berbeda.

\section{Daftar Pustaka}

\section{Buku:}

\footnotetext{
${ }^{37}$ Data lapangan 2017
}

Andiko dan Harry Oktavian. 2014. Negosiasi Efektif untuk Konflik Sumber Daya Alam. Pekanbaru: Scale Up.

Foss, Karen A. and Sonja K. Foss. 1991. Women Speak: The Eloquence of Women's Lives. Waveland $\mathrm{Pr}$ Inc (March 1991)

Hunga, Arianti Ina R. (2013). Ekofeminisme, Krisis Ekologis dan Pembangunan Berkelanjutan. Dalam Ekofeminisme (dalam tafsir agama, pendidikan, ekonomi dan Budaya).

Kartika, Titiek. (2014). Perempuan Lokal vs Tambang Pasir Besi Global. Jakarta: Yayasan Pustaka Obor Indonesia

Laura Kray \& Linda Babcock. (2015). "Gender in Negotiations: A Motivated Social Cognitive Analysis, in Negotiation Theory and Research 203" (Leigh L. Thompson ed., 2006) Shepherd 2015.

Littlejohn, Stephen dan Karen A. Foss. (2011).

Theories of Human Communication Tenth Edition. Illinois: Waveland Press.

Rakhmat, Jalaluddin. (2009). Psikologi Komunikasi. Bandung: PT. Remaja Rosdakarya.

Shiva, Vandana dan Maria Mies. (2005).

Ecofeminism perspektif gerakan perempuan dan lingkungan. Yogyakarta: Ire Press

Umar, Risma (edtr). (2012). Mengurai Realita Pemiskinan Perempuan di Tengah Konflik Sumber Daya Alam: Merekam Kasus-kasus Konflik Sumber Daya Alam. Solidaritas Perempuan (2008-2011)

\section{Jurnal:}

Dony Danardono. (2013). "Ekofeminisme: Kontradiksi Kapitalisme dan Etika Kepedulian". Ekofeminisme Dalam Tafsir Agama, Pendidikan, Ekonomi dan Budaya. 43-54 
Eliasoph, Nina. (1987). Politeness, Power, and Women's Language: Rethinking Study in Language and Gender. Berkeley Journal of Sociology, Vol. 32 (1987), pp. 79-103 Published by: Regents of the University of California Stable 2014.

Jalal, Moch. (2009). Fenomena Bias Gender dalam Pemakaian Bahasa Indonesia.

Media Masyarakat Kebudayaan dan Politik. Volume : 22 - No. 2 - 200904-01

Katubi. (2005). Membaca Posisi Wanita Melalui Bahasa: Deretan Temuan Penelitian Tanpa Implikasi Teoretis. Jurnal Masyarakat dan Budaya, Volume VII No. 2 Tahun 2005

Mohindra, Vinita and Samina Azhar. (2012).

Gender Communication: A Comparative Analysis of Communicational Approaches of Men and Women at Workplaces. IOSR Journal of Humanities and Social Science (JHSS) ISSN: 22790837, ISBN: 2279-0845. Volume 2, Issue 1 (Sep-Oct. 2012), PP 18-27 www.iosrjournals.org

Nazir, Barirah. (2012). Gender Patterns on Facebook: A Sociolinguistic. International Journal of Linguistics ISSN 1948-5425 2012, Vol. 4, No. 3. doi:10.5296/ijl.v4i3.1899

Ogunsiji, Yemi, Farinde R.O, \& Adebiyi C.O. (2012). "Language, Gender and Culture". British Journal of Arts and Social Sciences ISSN: 2046-9578, Vol.6 No.2. British Journal Publishing, Inc.

Shepherd, Cassandra K. (2015) "The Role of Women in International Conflict Resolution," Hamline University's School of Law's Journal of Public
Law and Policy: Vol. 36: Iss. 2, Article 1.

Usboko, Ignasius. (2016). Role Players Analysis dalam Konflik Pengelolaan Sumber Daya Alam (Studi Kasus Konflik Pertambangan Mangan Di Kabupaten Timor Tengah Selatan, Provinsi Nusa Tenggara Timur Tahun 2010-2011). POLITIKA, Vol. 7, No.1, April 2016

\section{Lain-lain:}

Berdasarkan catatan Analisis Dampak Lingkungan (ANDAL) yang disetujui oleh Badan Lingkungan Hidup Provinsi Bengkulu (BLH).

Buletin DTE edisi khusus No 99-100, Oktober 2014.

Catatan Akhir Tahun Konsorsium Pembaruan Agraria tahun 2015

Data lapangan 2017

Guhathakurta, Meghna. (2004). Women in Peace-building. Diakses pada 6 Desember 2016. Pukul 15:16 WIB.

PKWG Seminar Series \#2: Perempuan, Eksploitasi Alam, dan Pemiskinan" terselenggara di Auditorium Juwono Sudarsono FISIP UI - Kampus UI Depok pada 17 September 2015.

Sumber Data: Genesis Bengkulu dan WALHI Wawancara dengan Titiek Katika 21 Februari 2017, di Gedung Dekanat Universitas Bengkulu. 